\title{
Periplasmic synthesis and purification of the human prolactin antagonist $\Delta_{1-11}-\mathrm{G} 129 \mathrm{R}-\mathrm{hPRL}$
}

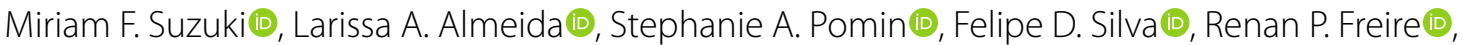

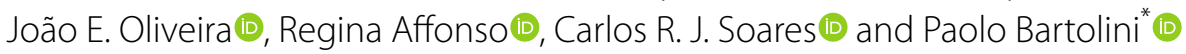

\begin{abstract}
The human prolactin antagonist $\triangle_{1-11}$-G129R-hPRL is a $21.9 \mathrm{kDa}$ recombinant protein with 188 amino acids that downregulates the proliferation of a variety of cells expressing prolactin receptors. Periplasmic expression of recombinant proteins in E. coli has been considered an option for obtaining a soluble and correctly folded protein, as an alternative to cytoplasmic production. The aim of this work was, therefore, to synthesize for the first time, the $\triangle_{1-11}-\mathrm{G} 129 \mathrm{R}$ hPRL antagonist, testing different activation temperatures and purifying it by classical chromatographic techniques. $E$. coli BL21(DE3) strain was transformed with a plasmid based on the pET25b(+) vector, DsbA signal sequence and the antagonist cDNA sequence. Different doses of IPTG were added, activating under different temperatures, and extracting the periplasmic fluid via osmotic shock. The best conditions were achieved by activating at $35^{\circ} \mathrm{C}$ for $5 \mathrm{~h}$ using $0.4 \mathrm{mM}$ IPTG, which gave a specific expression of $0.157 \pm 0.015 \mu \mathrm{g} / \mathrm{mL} / \mathrm{A}_{600}$ at a final optical density of $3.43 \pm 0.13 \mathrm{~A}_{600}$. Purification was carried out by nickel-affinity chromatography followed by size-exclusion chromatography, quantification being performed via high-performance size-exclusion chromatography (HPSEC). The prolactin antagonist was characterized by SDS-PAGE, Western blotting, reversed-phase high-performance liquid chromatography (RP-HPLC) and MALDI-TOF-MS. The final product presented $>95 \%$ purity and its antagonistic effects were evaluated in vitro in view of potential clinical applications, including inhibition of the proliferation of cancer cells overexpressing the prolactin receptor and specific antidiabetic properties, taking also advantage of the fact that this antagonist was obtained in a soluble and correctly folded form and without an initial methionine.
\end{abstract}

Keywords: Prolactin antagonist, Periplasmic expression, DsbA signal peptide, Antagonistic properties

\section{Introduction}

Recombinant human prolactin antagonists are potential drugs that inhibit target prolactin receptors in dopamineresistant prolactinomas, breast cancer, prostate cancer, and ovary cancer, in all cases where autocrine PRL acts as growth promoting agent, or even for pain release and to avoid hair loss (O'Sullivan and Bates 2016). There are several PRLR antagonists reported in the literature (Goffin

\footnotetext{
*Correspondence: pbartoli@ipen.br

Biotechnology Center, Instituto de Pesquisas Energéticas e Nucleares, IPEN-CNEN/SP, Avenida Prof. Lineu Prestes 2242, São Paulo, SP 05508-000, Brazil
}

2017; Tallet et al. 2008) that downregulate the proliferation of a variety of cells expressing prolactin receptors: G129R-hPRL (Chen et al. 1999), S179D-hPRL (Chen et al. 1998), $\Delta_{1-9-}$ G129R-hPRL and $\Delta_{1-14}$-G129R-hPRL (Bernichtein et al 2003a, b, c), $\Delta_{1-9}$-C11S-S33A-Q73LG129R-K190R-hPRL (Yu et al. 2019) and also G120RhGH (Menezes et al. 2017). All prolactin antagonists have been up to now synthesized as inclusion bodies in the cytoplasm of $E$. coli (Chen et al. 1998; Oclon et al. 2018; Yu et al. 2019), or secreted into the medium by transfected CHO cells (Soares et al. 2006; Swiech et al. 2012) or mouse L-cells (Chen et al. 1998). Periplasmic expression of recombinant proteins in E. coli has been 
considered to be a valid option for obtaining a soluble and correctly folded protein, as an alternative to the cytoplasmic production, in inclusion bodies, of an unfolded, insoluble protein carrying an extra initial methionine (Dalmora et al. 1997; Dias et al. 2018; Menezes et al. 2017; Morganti et al. 1998; Sockolosky and Szoka 2013; Suzuki et al. 2012; Taherian et al. 2019).

The importance of prolactin receptor antagonists is especially related to their potential to antagonize the tumor growth-promoting effects of hPRL in vivo, in animal models of breast and prostate cancer (Chen et al. 2002; Xu et al. 2001), and to their antiangiogenic properties (Ueda et al. 2006; 2009). More recently, they have been described as promising therapeutic agents to control blood glucose levels, showing antidiabetic properties (Capone et al. 2015; Furigo et al. 2019; Menezes et al. 2017).

$\Delta_{1-11}$-G129R-hPRL is a novel hPRL antagonist obtained by deleting eleven $\mathrm{N}$-terminal residues of the well-known prolactin receptor antagonist G129R-hPRL. It is therefore a $21.9 \mathrm{kDa}$ protein with 188 amino acids and pI 6.15. It has been reported that, by eliminating the first disulfide bond (C4-C11) forming the ring structure of the cystine knot, the protein loses any agonistic properties (Bernichtein et al. 2003a, b, c). The aim of this work was the expression of the $\Delta_{1-11}$-G129R-hPRL antagonist in the periplasm of $E$. coli, its purification and physical-chemical characterization and evaluation of its antagonistic effects using mouse lymphoblastic cells transfected with the human prolactin receptor (Bernichtein et al. 2003a, $\mathrm{b}, \mathrm{c})$. This homologous lactogenic assay (Ba/F3-LLP) is based on the Low Low cell Population (LLP) bioassay (Glezer et al. 2006), which has a sensitivity of the same order as the widely applied $\mathrm{Nb} 2$ bioassay and is about tenfold more sensitive than the original Ba/F3-LP assay (Bernichtein et al. 2003a, b, c; Paraiba et al. 2010).

\section{Materials and methods}

\section{Strain and expression conditions}

The E. coli BL21(DE3) strain was transformed with the pET25b $(+)$ vector containing the DsbA (a bacterial disulfide oxireductase) signal sequence followed by the $\Delta_{1-9}$-G129R-hPRL antagonist cDNA and ampicillin resistance-sequences (database for human prolactin from NCBI reference sequence NP_000939.1 and consensus CDS 4548.1). Besides the substitution of the natural signal peptide by the DsbA signal peptide, the deletion of the initial 27 nucleotides and a substitution of glycine 129 , codon GGC, by arginine, codon CGC, were also introduced. The plasmid was constructed using NdeI and BamHI restriction sites (Biomatik Custom Gene Synthesis Service, Cambridge, Ontario, Canada) without any His-tag sequence. After overnight culture at $37{ }^{\circ} \mathrm{C}$, plasmids were extracted, analyzed by digestion to confirm the presence of the inserts, and sequenced by the Sanger method to confirm the correct DNA sequence. The BigDye Terminator v 3.1 Cycle Sequencing Kit was used, and amplicons were sequenced in an ABI 3730 DNA Analyzer (Life Technologies-Applied Biosystems/ Hitachi, Foster City, CA, USA). All data were obtained via Sequencing Analysis 5.3.1.

The transformed bacteria were cultured in $100 \mathrm{~mL}$ Luria-Bertani broth (LB broth) with $0.1 \mathrm{mg} / \mathrm{mL}$ ampicillin, under rotational shaking $(150 \mathrm{rpm})$ in $250 \mathrm{~mL}$ Erlenmeyer flasks. After overnight culture at $30{ }^{\circ} \mathrm{C}$, recombinant protein production was evaluated at different temperatures $\left(25,30,32,35\right.$ and $\left.37^{\circ} \mathrm{C}\right)$ for $5 \mathrm{~h}$, with different doses of IPTG $(0.2 ; 0.4 ; 0.6 ; 0.8$ and $1.0 \mathrm{mM})$. The periplasmic fluid was then obtained by osmotic shock.

\section{Osmotic shock}

Periplasmic fluid was extracted after harvesting the bacteria by centrifugation at $3000 \times \mathrm{g}$ for $10 \mathrm{~min}$ as described (Sockolosky and Szoka 2013). Briefly, pellets were resuspended in hypertonic solution consisting of $10 \mathrm{mM}$ Tris$\mathrm{HCl} \mathrm{pH} \mathrm{7.5,} \mathrm{adding} 1 \mathrm{~mL}$ of $20 \%$ sucrose (w/v) and $33 \mu \mathrm{L}$ $0.5 \mathrm{M}$ EDTA pH 8.0 for each $100 \mathrm{~A}_{600}$ units. After $10 \mathrm{~min}$ in an ice bath, the bacteria were centrifuged at $3000 \times \mathrm{g}$ for $10 \mathrm{~min}$. The pellet was resuspended with $1 \mathrm{~mL}$ of a hypotonic solution of $1 \mathrm{mM}$ Tris- $\mathrm{HCl} \mathrm{pH} 7.5$ per each $100 \mathrm{~A}_{600}$ units, incubating then in an ice bath for $10 \mathrm{~min}$. After centrifuging at $3000 \times \mathrm{g}$ for $10 \mathrm{~min}$, the collected supernatant represented the periplasmic fluid, which was stored at $-80{ }^{\circ} \mathrm{C}$, analyzed by SDS-PAGE, Western blotting and RP-HPLC.

\section{SDS-PAGE, Western blotting and RP-HPLC qualitative and quantitative analyses}

15\% Polyacrylamide gel electrophoresis (SDS-PAGE) was carried out under non-reducing conditions, staining with Coomassie brilliant blue G-250 (USB, Cleveland, OH, USA) (Laemmli 1970; Soares et al. 2003). Western blotting analysis was performed using semidry transfer on a nitrocellulose membrane. A rabbit anti-hPRL primary antibody $(1: 1,000)$ and a secondary HRP conjugated goat anti-rabbit Ig-G $(1: 10,000)$ were used (R\&D Systems, Minneapolis, MN, USA) (Soares et al. 2003). The images were obtained by chemiluminescence (Immobilon Western Chemiluminescent HRP Substrate, Millipore Corporation, Billerica, MA, USA) using an UVITEC photo documenter System (Cambridge, United Kingdom) (Capone et al. 2015). RP-HPLC was used for the qualitative and quantitative analysis of this protein in all steps of purification, with a Shimadzu model SCL-10A HPLC apparatus coupled 


\section{a}

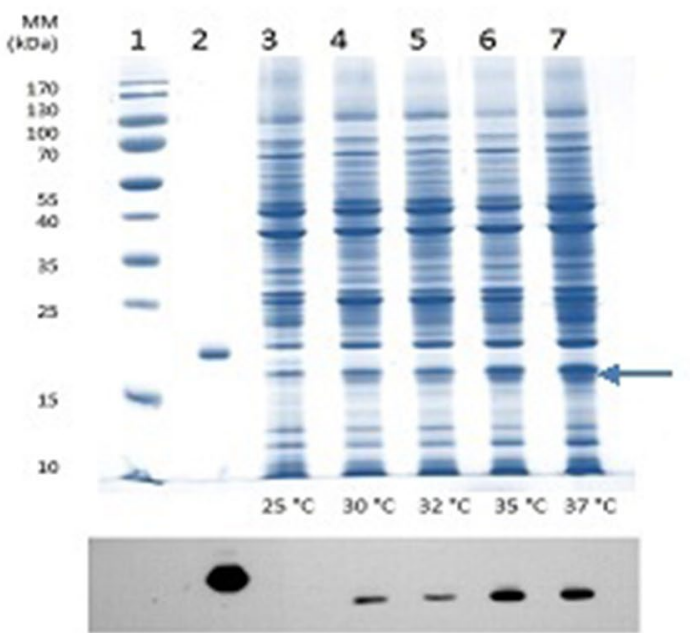

b

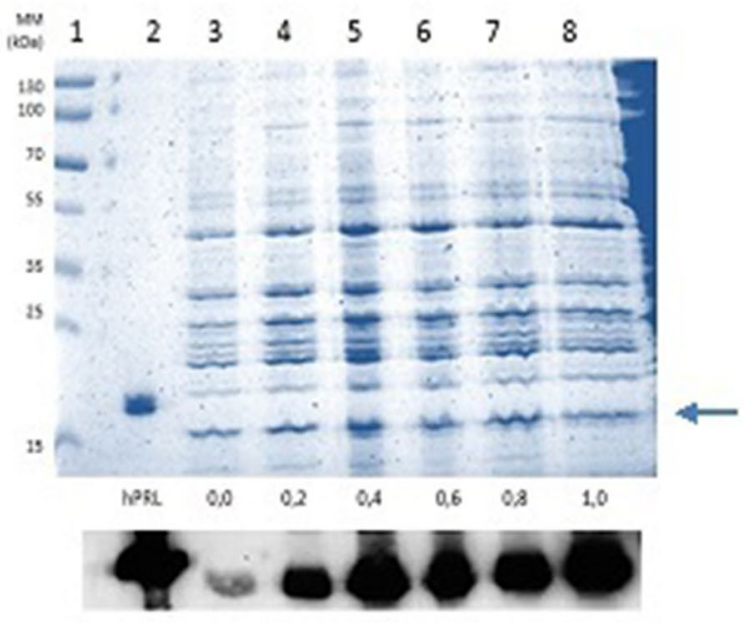

Fig. 1 SDS-PAGE under non-reducing conditions and Western Blotting with samples of periplasmic fluid obtained from E. coli BL21(DE3) by osmotic shock, after 5 h of cultivation with $0.4 \mathrm{mM} \mathrm{IPTG}$ at different temperatures: $25^{\circ} \mathrm{C}, 30^{\circ} \mathrm{C}, 32^{\circ} \mathrm{C}, 35^{\circ} \mathrm{C}$ and $37^{\circ} \mathrm{C}(\mathbf{a})$ and at $25^{\circ} \mathrm{C}$ with different IPTG concentrations: $0.2 \mathrm{mM}, 0.4 \mathrm{mM}, 0.6 \mathrm{mM}, 0.8 \mathrm{mM}$ and $1.0 \mathrm{mM}$. b Lane 1: molecular mass marker, lane 2: recombinant human prolactin internal standard $(23 \mathrm{kDa})$. The arrows indicate the position of $\triangle_{1-11}-\mathrm{G} 129 \mathrm{R}-\mathrm{hPRL}(22 \mathrm{kDa})$

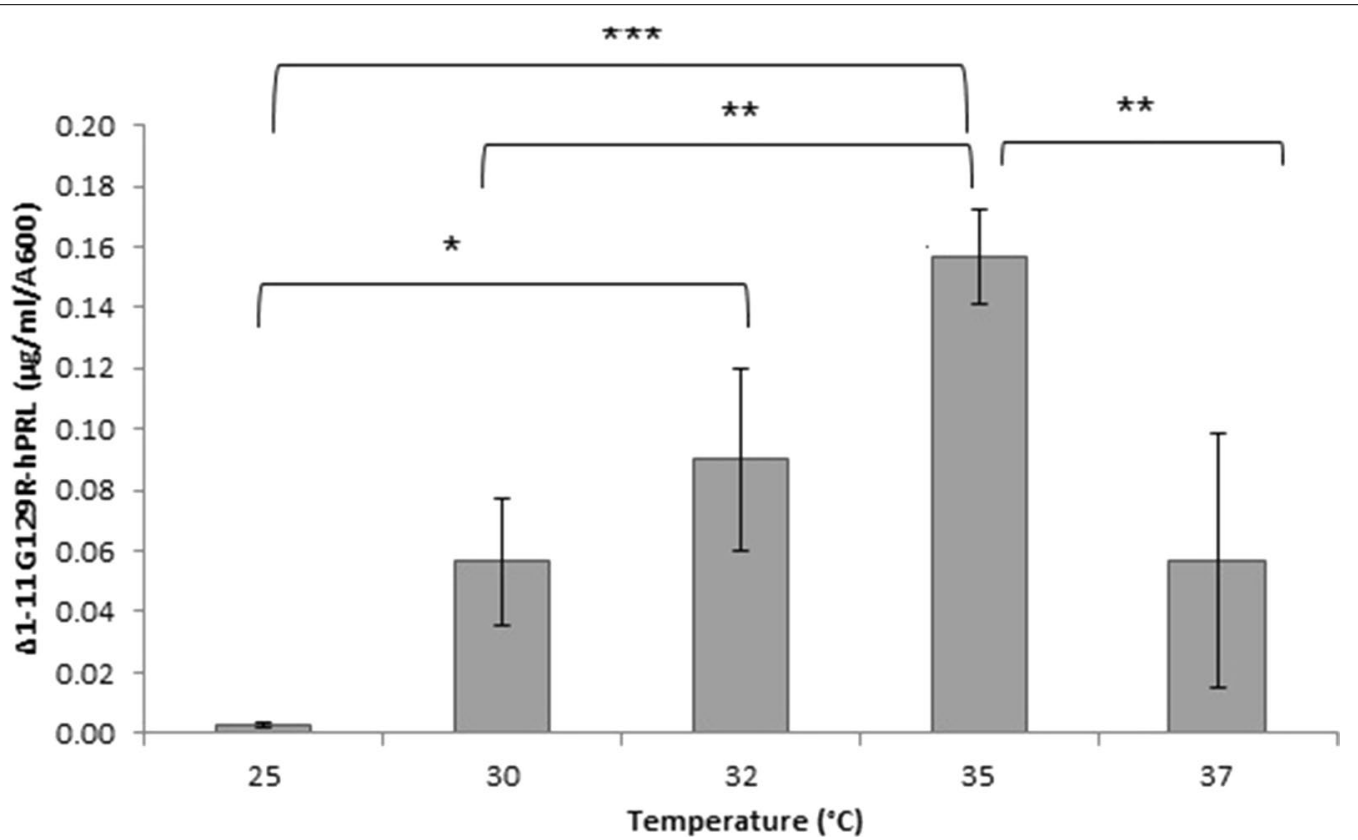

Fig. 2 Influence of the temperature on $\triangle_{1-11}-$ G129R-hPRL synthesis $(n=3) 5 \mathrm{~h}$ after addition of $0.4 \mathrm{mM}$ IPTG to the E. coli BL21 (DE3) culture. ${ }^{*} \mathrm{P}<0.05,{ }^{* * P}<0.01,{ }^{* * *} \mathrm{P}<0.001$

to a SPD-10AV UV detector with a Class VP software (Shimadzu, MD, USA) connected to a C4 Vydac 214TP54 column $(25 \mathrm{~cm} \times 4.6 \mathrm{~mm}$ ID, pore diameter of $300 \AA$ and particle diameter of $5 \mu \mathrm{m}$, Hesperia, CA,
USA), and a silica precolumn packed with LiChrosorb Si-60, 7.9-12.4 $\mu \mathrm{m}$ (Merck, Darmstadt, Germany), as described (Soares et al. 2002). The mobile phase consisted of $71 \% 50 \mathrm{mM}$ Tris- $\mathrm{HCl}$ buffer, $\mathrm{pH} 7.5$, and $29 \%$ n-propanol, with a flow rate of $0.5 \mathrm{~mL} / \mathrm{min}$, column 


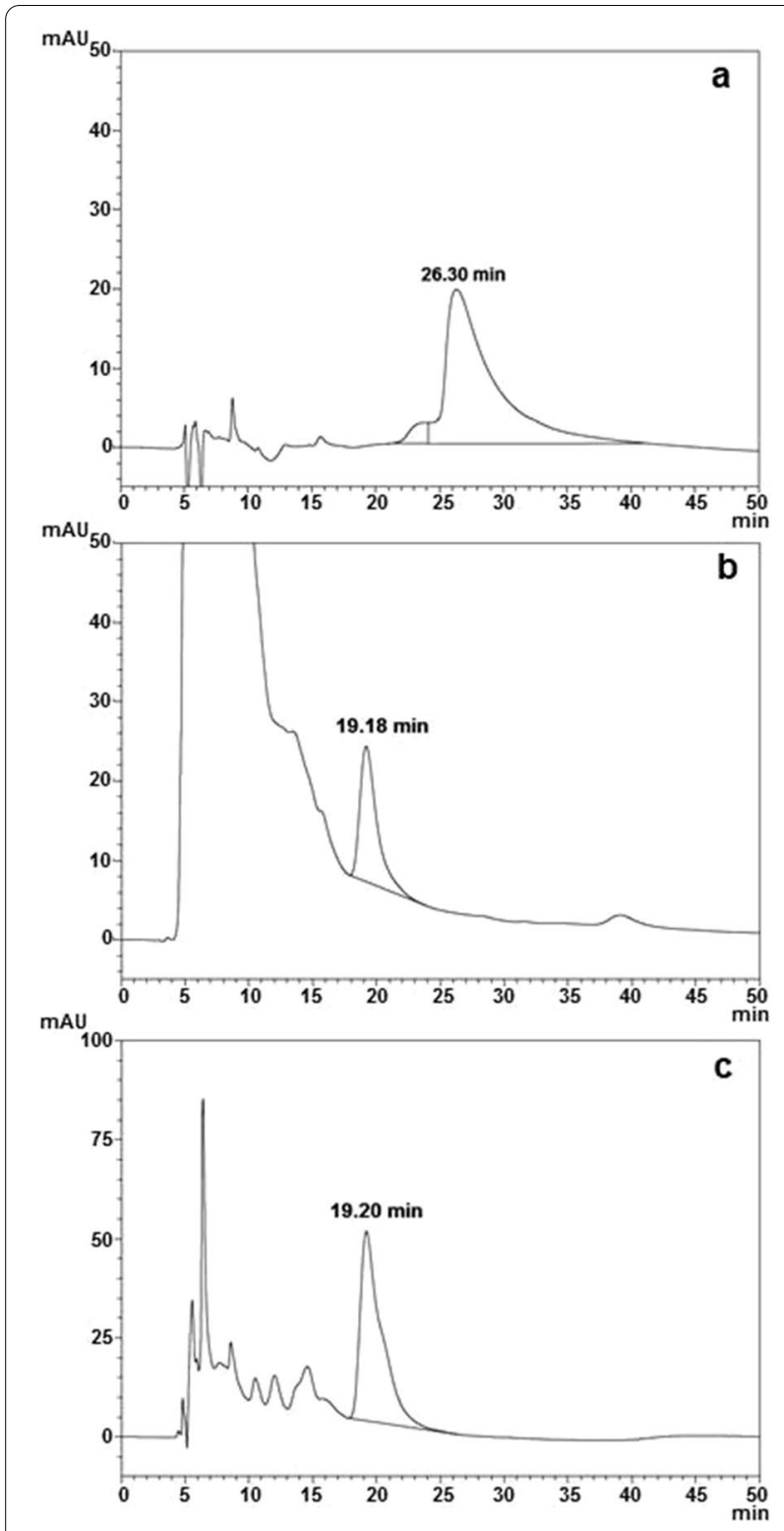

Fig. 3 RP-HPLC analysis of: a hPRL internal standard with retention time $\left(t_{R}\right)$ of 26.30 min; $\mathbf{b} \Delta_{1-11}$-G129R-hPRL, before purification from periplasmic fluid, with $t_{R}$ of 19.18 min; c $\Delta_{1-11}-G 129 R-h P R L$ after the two-step purification process, with $t_{R}=19.20$. A C4 Vydac 214TP54 column $(25 \mathrm{~cm} \times 4.6 \mathrm{~mm} \mathrm{ID})$ was used. The mobile phase consisted of $71 \% 50 \mathrm{mM}$ Tris- $\mathrm{HCl}$ buffer, $\mathrm{pH} 7.5$, and $29 \%$ n-propanol, with a flow rate of $0.5 \mathrm{ml} / \mathrm{min}$, column temperature maintained at $45^{\circ} \mathrm{C}$, monitoring at $220 \mathrm{~nm}$ and applying a sample volume of $10 \mu \mathrm{L}$ (a) or $100 \mu \mathrm{L}(\mathbf{b}, \mathbf{c})$

temperature maintained at $45^{\circ} \mathrm{C}$, monitoring at $220 \mathrm{~nm}$ and applying a sample volume of $10-500 \mu \mathrm{L}$ (Dalmora et al. 1997). The antagonist was quantified by determining the area under the curve against the Internal Standard of rec-hPRL and the International Standard of rec-hGH, coded WHO 98/574 (Soares et al. 2008).

\section{Purification process}

Purification was carried out by automated nickel affinity chromatography followed by size exclusion chromatography (SEC) (Ueda et al. 2001). Before purification, a dialysis against $0.05 \mathrm{M}$ sodium phosphate buffer, $\mathrm{pH}$ 7.2, was conducted to eliminate traces of EDTA, used for osmotic shock. The first purification step of $\Delta_{1-11}$-G129RhPRL from the periplasmic fluid was conducted by nickel affinity chromatography (IMAC-HisPrep ${ }^{\text {TM }}$ FF16/10, GE Healthcare Bio-Sciences AB, Uppsala, Sweden) with $0.02 \mathrm{M}$ sodium phosphate, $\mathrm{pH} 7.2,0.8 \mathrm{M} \mathrm{NaCl}$ as buffer A (flow rate $5 \mathrm{~mL} / \mathrm{min}$, particle size $90 \mu \mathrm{m}$, bed volume $20 \mathrm{~mL}$, pressure limit of $0.5 \mathrm{MPa}$ ) and $100 \mathrm{mM}$ imidazole as buffer B. After equilibrating the column with $0.3 \mathrm{M}$ $\mathrm{NiSO}_{4}$, the dialyzed periplasmic fluid was injected onto the column and two steps of $10 \mathrm{mM}$ and $20 \mathrm{mM}$ imidazole ( 5 column volumes each) and one linear gradient of $20 \mathrm{mM}$ to $100 \mathrm{mM}$ imidazole (5 column volumes) were carried out. During this process, $5 \mathrm{~mL}$ fractions were collected. Considering the natural affinity of hPRL for nickel, no his-tag was introduced.

A pool of fractions containing the antagonist was then applied to a SEC column after concentration by centrifugation via an Amicon ${ }^{\circledR}$ Ultra 15 (centrifugal filter devices, Merck Millipore Ltd., Tullagreen, Carrigtwohill, Co. Cork, Ireland) at $5000 \mathrm{~g}$, with fixed-angle rotor up to $40 \mathrm{~mL}$. The resin was Sephacryl S-100, packed in a $26 \times 100 \mathrm{~mm}$ column and running under isocratic conditions, with $0.02 \mathrm{M}$ sodium phosphate buffer, $\mathrm{pH} 7.2$, at a flow rate of $1 \mathrm{~mL} / \mathrm{min}$ and pressure limit of $0.4 \mathrm{MPa}$. Fractions of $2 \mathrm{~mL}$ were collected and stored at $-80^{\circ} \mathrm{C}$.

In both cases, the purification was carried out using an ÄKTA purification system (GE Health Sciences, Buckinghamshire, UK) (Menezes et al. 2017; Silva et al. 2019).

\section{HPSEC and mass spectral characterization}

Final quantification was carried out via HPSEC with the same Shimadzu apparatus, connected to a TosoHaas G2000 SW column $(60 \mathrm{~cm} \times 7.5 \mathrm{~mm}$ ID, particle size of $10 \mu \mathrm{m}$ and pore size of $125 \AA$ ) coupled to a $7.5 \times 7.5 \mathrm{~mm}$ ID SW guard column (Montgomeryville, PA, USA). The mobile phase was $0.025 \mathrm{M}$ ammonium bicarbonate, $\mathrm{pH}$ 
7.0, with a flow rate of $1.0 \mathrm{~mL} / \mathrm{min}$ (Soares et al. 2002). The final product was also analyzed by MALDI-TOF MS. The exact molecular mass was determined by MALDITOF Autoflex Speed (Bruker Daltonics Inc., Billerica, MA, USA) using a sinapinic acid mixture $(10 \mathrm{mg} / \mathrm{mL}$ TA30: $30 \%$ acetonitrile, $0.1 \%$ TFA): sample dilution 1:1 $(\mathrm{v} / \mathrm{v})$. The mixture was applied on a GroundSteel plate and analyzed between 10 and $30 \mathrm{kDa}$. The acquisition mode was linear with positive polarity (Protparam program) (Silva et al. 2019).

\section{$\mathrm{N}$-terminal amino acid determination}

The N-terminal amino acid sequence of the $\Delta_{1-11}$-G129RhPRL was determined with the protein and peptide sequencer system (Model PPSQ-21, Shimadzu, Kyoto, Japan) through automated Edman Degradation, directly from a pure liquid sample at $100 \mu \mathrm{g} / \mathrm{mL}$ (Edman and Begg 1967).

\section{In vitro bioassay}

The Ba/F3-LLP proliferation assay based on mouse lymphoblastic cells was applied to confirm the agonistic and antagonistic effects of this molecule (Menezes et al. 2017; Soares et al. 2006). These cells express human PRL receptor long isoform and have geneticin resistance. The maximum proliferation is obtained with $1 \mathrm{ng} / \mathrm{mL}$ of PRL in RPMI-1640 culture medium, supplemented with $10 \%$ heat inactivated FSB and $50 \mathrm{U} /$ $\mathrm{mL}$ of penicillin, $50 \mu \mathrm{g} / \mathrm{mL}$ of streptomycin, $700 \mu \mathrm{g} / \mathrm{mL}$ of geneticin (G418, Sigma). Before the assay, the cells were starved for $12 \mathrm{~h}$ in RPMI-1640 medium containing $1 \%$ FBS. Cells were then distributed in a flat bottom 96 well-plate at a density of $2 \times 10^{4}$ cells/well in a final volume of $100 \mu \mathrm{L}$ of medium with $1 \%$ FBS and antibiotics. hPRL at concentration of $0.025 \mathrm{ng} / \mathrm{mL}$ to $1 \mathrm{ng} /$ $\mathrm{mL}$ in $100 \mu \mathrm{L}$ medium was added to each well for the standard curve. The antagonist alone, or with hPRL, was added in serial dilutions for proliferation evaluation. After $72 \mathrm{~h}$ at $37{ }^{\circ} \mathrm{C}$ and $5 \% \mathrm{CO}_{2}$, the MTS assay was carried out as reported in the protocol (Promega Corp., Madison, WI, USA). After $2 \mathrm{~h}$ of incubation with $20 \mu \mathrm{L}$ of the MTS/PMS mixture (v/v; 20:1), the absorbance at $490 \mathrm{~nm}$ was read in a microplate reader (Dynatech, model MR4000, Chantilly, VA, USA) (Soares et al.
2006). The recombinant hPRL International Standard (WHO-97/714), with a declared biological activity of $57.2 \pm 11.4 \mathrm{IU} / \mathrm{mg}$, was used for the standard curve (Paraiba et al. 2010).

\section{Statistical analyses}

The results are expressed as mean \pm standard deviation. Data were analyzed using one-way ANOVA and Tukey multi-comparisons. PRISM 6 (GraphPad, La Jolla, CA, USA.) software was used for the statistical analyses and only $\mathrm{P}$ values $<0.05$ were considered to be statistically significant.

\section{Results \\ Effects of temperature and IPTG concentration on the expression level}

The best conditions for producing the $\Delta_{1-11^{-G}}$ - $29 \mathrm{R}-\mathrm{hPRL}$ antagonist were confirmed at a temperature of $35{ }^{\circ} \mathrm{C}$ (Fig. 1a) for $5 \mathrm{~h}$ with $0.4 \mathrm{mM}$ IPTG (Fig. 1b).

The periplasmic fluid was analyzed by RP-HPLC and a specific expression of $0.157 \pm 0.015 \mu \mathrm{g} / \mathrm{mL} / \mathrm{A}_{600}, \mathrm{n}=3$ (Fig. 2) with a final optical density of $3.43 \pm 0.13 \mathrm{~A}_{600}$ $(\mathrm{n}=3)$ was obtained in the Erlenmeyer incubation flasks.

The analysis of the periplasmic fluid carried out before purification showed a retention time $\left(t_{R}\right)$ of $19.18 \mathrm{~min}$ for the $\Delta_{1-11}$-G129R-hPRL antagonist, which is lower than that of hPRL (26.30 min), indicating a lower hydrophobicity (Fig. 3a, b). The hydrophobicity of $\Delta_{1-11}$-G129hPRL was then confirmed via the same RP-HPLC, analyzing now the final purified product, without the presence of the large amount of material that appeared in the initial part of the chromatogram (Fig. 3c) and that might potentially have influenced the antagonist $t_{R}$. As can be observed, the antagonist $t_{R}$ of 19.20 min was perfectly maintained even after purification (Fig. 3c).

\section{Purification of $\Delta_{1-11}-$ G129R-hPRL from periplasmic fluid}

The two-step purification was developed using the periplasmic fluid from a $3 \mathrm{~L}$ culture of BL21(DE3)-derived $\Delta_{1-11}$-G129R-hPRL. The first step, using metal affinity chromatography (Hisprep Fast Flow 16/10), was carried out as described for G129R-hPRL (Furigo et al. 2019). The pool of fractions \#54 to \#62 (Fig. 4a) corresponded to $80 \mathrm{mM}$ imidazole elution, as was the case of G129RhPRL (Furigo et al. 2019). The pool containing $\Delta_{1-11^{-}}$ G129R-hPRL was used for the second purification step 

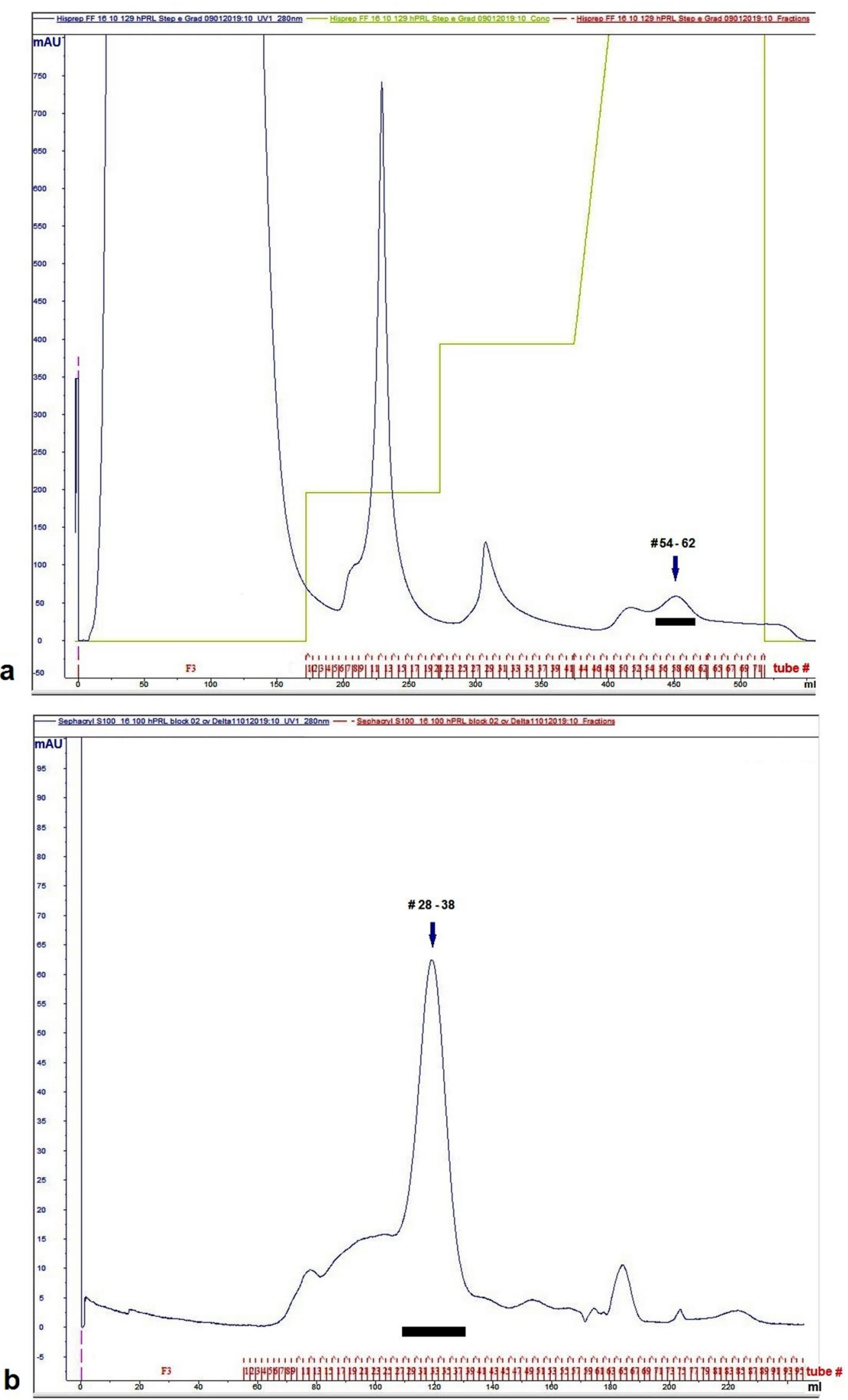


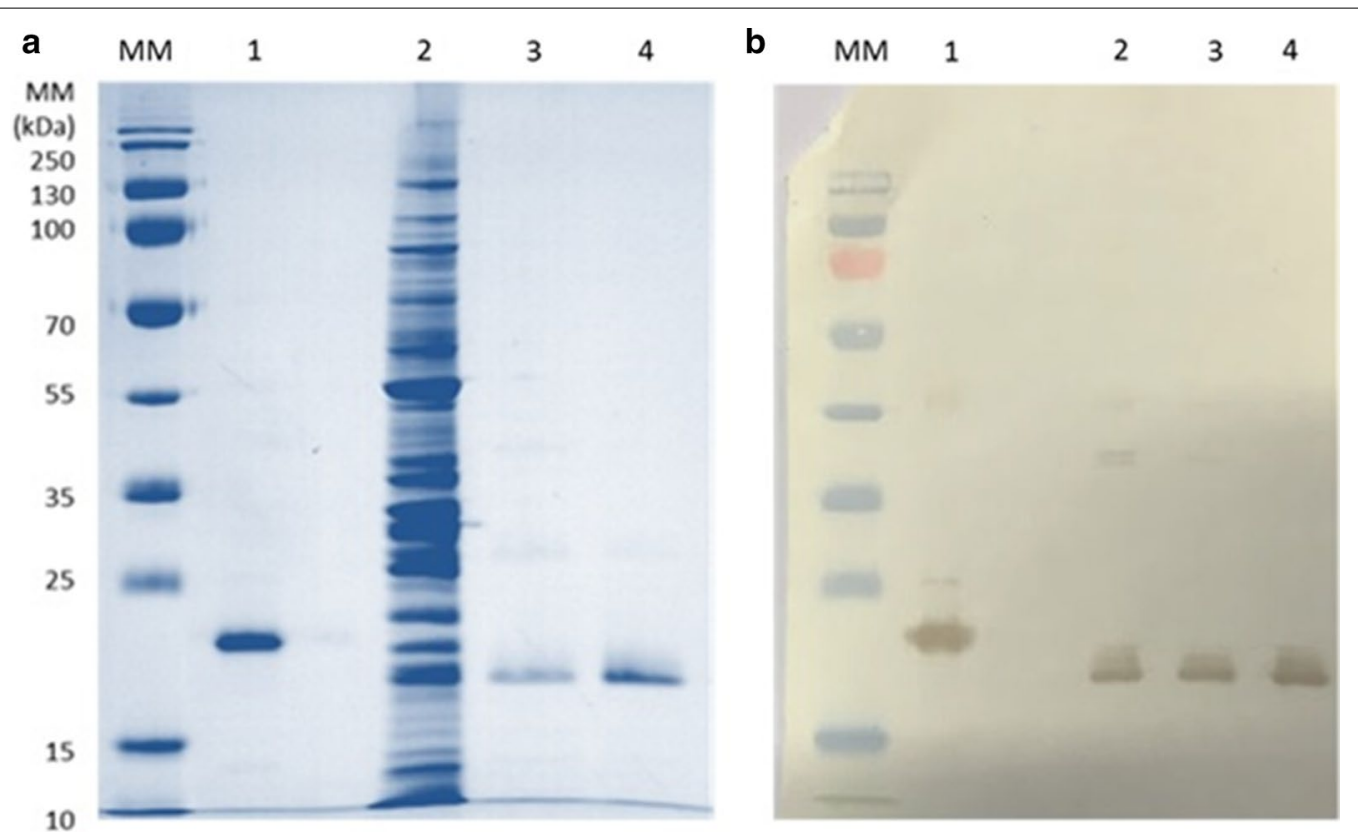

Fig. 5 Comparative analysis of the chromatographic steps of $\triangle_{1-11}$-G129R-hPRL by SDS-PAGE under non-reducing conditions (a) and Western Blotting (b). (MM) molecular mass standards, (1) hPRL, (2) periplasmic fluid, (3) pool from IMAC and (4) pool from SEC

via size-exclusion chromatography (SEC, Sephacryl $\mathrm{S}-100)$, the final product being eluted in fractions \#28 to \#38 (Fig. 4b).

The SDS-PAGE (Fig. 5a) and Western Blotting (Fig. 5b) of samples before purification (lane 2) and after the two purification steps (lanes 3 and 4) showed the efficacy of the chromatographic techniques applied.

Most of periplasmic proteins were eliminated just after the first purification step, as confirmed by HPSEC analysis (Fig. 6a): the main peak, with $\mathrm{t}_{\mathrm{R}} 15.96 \mathrm{~min}$, corresponds to $\Delta_{1-11}-$ G129R-hPRL and four contaminants were also still present. The final product, obtained by elution of the main peak, showed $>95 \%$ purity by HPSEC analysis, with a $t_{R}=16.03$ min (Fig. 6b). The area under the peak of hPRL was used for quantification (Fig. 6c). A volumetric yield of $0.54 \mu \mathrm{g} / \mathrm{mL}$ antagonist, with purity above $95 \%$, was obtained.

Table 1 shows the recovery and purity after each purification step, starting from a $3 \mathrm{~L}$ culture broth.

MALDI-TOF-MS was used to confirm the theoretical molecular mass (MM) of $\Delta_{1-11}$-G129R-hPRL: 21,958.03 Da. Two independent assays determined a MM of $21,963.48 \mathrm{Da}(+0.025 \%)$ and $21,952.59 \mathrm{Da}$ $(-0.029 \%)$ (Fig. 7), confirming the high accuracy offered by this methodology.

\section{$\mathrm{N}$-terminal data}

The eight $\mathrm{N}$-terminal amino acids of the $\Delta_{1-11}$ G129RhPRL were determined as QVTLRDLF, lacking the two cysteines of the first disulfide bond (C4-C11) of human prolactin LPICPGGAARCQVTLRDLF.

\section{In vitro biological activity determination}

The Ba/F3-LLP proliferation assay based on mouse lymphoblastic cells confirmed the null agonistic effect of $\Delta_{1-11}$-G129R-hPRL up to $1000 \mathrm{ng} / \mathrm{mL}$ (Fig. 8a), while the antagonistic effect of this molecule was always significant, starting from a concentration of $7.8 \mathrm{ng} / \mathrm{mL}$ in the presence of $1 \mathrm{ng} / \mathrm{mL}$ of hPRL (Table 2) and reaching a value of $\sim 23 \%$ with a $\sim 16$-fold molar excess of the antagonist (Fig. 8b).

\section{Discussion}

For the first time, the human prolactin receptor antagonist $\Delta_{1-11}$-G129R-hPRL has been synthesized, following also the tendency of our research group of giving priority to periplasmic expression. As far as we know this is the only hPRL antagonist ever synthesized in $E$. coli periplasm. The most studied prolactin antagonist is $\Delta_{1-9}$-G129R-hPRL (Ferraris et al 2013; Goffin 2017; 


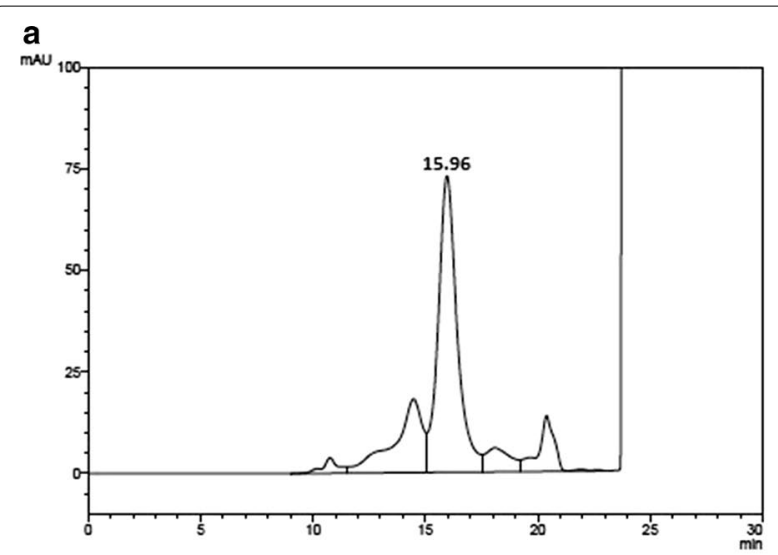

b

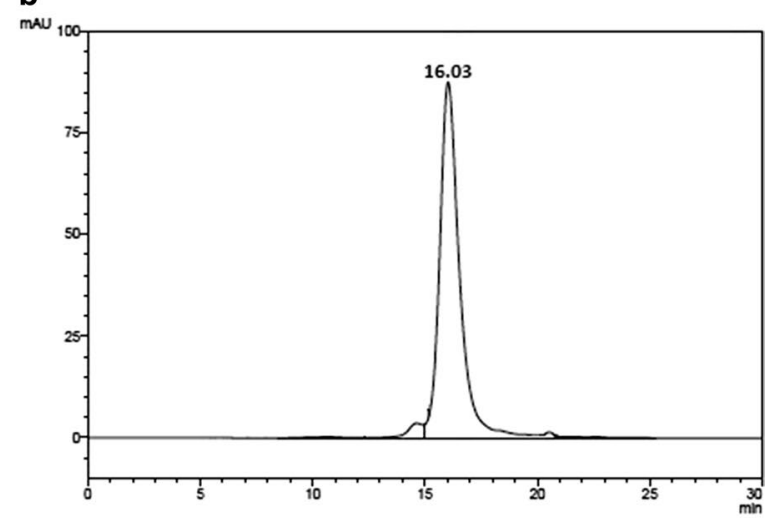

C

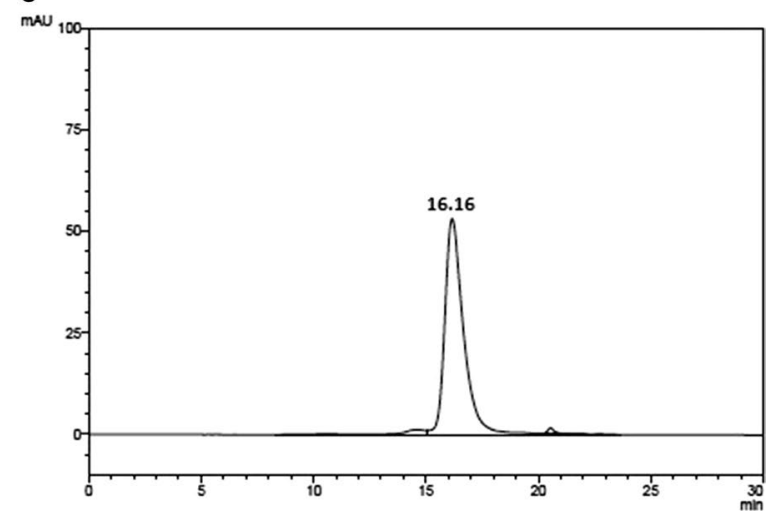

Fig. 6 HPSEC analysis of the pool of $\triangle_{1-11}-G 129 R-h P R L$ collected from IMAC (a) and from SEC (b) and of the internal standard of hPRL (c)

Table 1 Recovery and purity of $\Delta_{1-11}-$ G129R-hPRL after each purification step

\begin{tabular}{lccc}
\hline Purification step & $\begin{array}{l}\boldsymbol{\Delta}_{1-11-G 129 R-} \\
\text { hPRL }(\boldsymbol{\mu g})\end{array}$ & Recovery (\%) & $\begin{array}{l}\text { Purity } \\
\text { (\%) }\end{array}$ \\
\hline Periplasmic fluid & 3600 & - & - \\
IMAC (Hisprep FF) & 1160 & 32.2 & 65.7 \\
SEC (Sephacryl S100) & 884 & 76.2 & 96.5 \\
\hline
\end{tabular}

Jomain et al. 2007; Oclon et al. 2018; Tallet et al. 2008), even though no clinical trial has been effectively carried out yet. The plasmid used in the present study was the same that should produce the prolactin antagonist G129R-hPRL without the initial nine residues. After MALDI-TOF-MS analysis and N-terminal amino acid determination, the absence of the eleven N-terminal residues was confirmed. We speculate that the difference between $\Delta_{1-9^{-}}$and $\Delta_{1-11^{-}}$G129R-hPRL could be due to a proteolytic processing at the amino termini that only occurs in the periplasm. A specific investigation of the synthesis of this new antagonist would therefore be particularly interesting. Several prolactin variants are found in human plasma with $22 \mathrm{kDa}$, $21 \mathrm{kDa}, 16 \mathrm{kDa}, 8 \mathrm{kDa}$ and even $2 \mathrm{kDa}$ and $1 \mathrm{kDa}$, produced via proteolytic cleavage by kallikrein, a trypsinlike serine protease, or by a cathepsin D-like protease (Ben-Jonathan et al. 1996; Sinha 1992). Although $\Delta_{1-11^{-}}$ G129R-hPRL antagonist was obtained here from E. coli periplasmic fluid, the cytoplasmic synthesis of human prolactin, presenting truncated $\mathrm{N}$-termini up to the first 14 residues, did not show any undesired cleavage (Bernichtein et al. 2003a, b, c).

\section{Effects of temperature and IPTG concentration on the expression level}

The specific expression of $0.16 \mu \mathrm{g} / \mathrm{mL} / \mathrm{A}_{600}$ obtained for $\Delta_{1-11}$-G129R-hPRL at $35^{\circ} \mathrm{C}$ was lower than that obtained for G129R-hPRL at $35{ }^{\circ} \mathrm{C}: 0.49 \mu \mathrm{g} / \mathrm{mL}^{\circ} \mathrm{A}_{600}$ (Furigo et al. 2019), and much lower than the hPRL expression of $0.93 \mu \mathrm{g} / \mathrm{mL} / \mathrm{A}_{600}$ at $37{ }^{\circ} \mathrm{C}$ (Soares et al. 2008). Previous work on the periplasmic expression of the growth hormone antagonist G120R-hGH showed, in fact, that the highest specific productivity was obtained at $37{ }^{\circ} \mathrm{C}$ $\left(1.34 \mu \mathrm{g} / \mathrm{mL} / \mathrm{A}_{600}\right.$ ) (Menezes et al 2017), differently from our maximum $\mathrm{hGH}$ production obtained at $42{ }^{\circ} \mathrm{C}$ by using the repressor gene pRK248 cIts: $3.9 \mu \mathrm{g} / \mathrm{mL} /$ $\mathrm{A}_{600}$ (Soares et al. 2003). For hPRL, the highest production was obtained at $37{ }^{\circ} \mathrm{C}$ (Soares et al. 2008), while for G129R-hPRL this was at $35{ }^{\circ} \mathrm{C}$, using the lambda $\mathrm{P}_{\mathrm{L}}$ promoter and the W3110 strain (Furigo et al. 2019). Thus, in our hands, periplasmic prolactin and its variants required, in general, a lower expression temperature than $\mathrm{hGH}$. It is of note, moreover, that the periplasmic expression of hPRL and of its variants was generally quite problematic to the extent that the periplasmic production of 


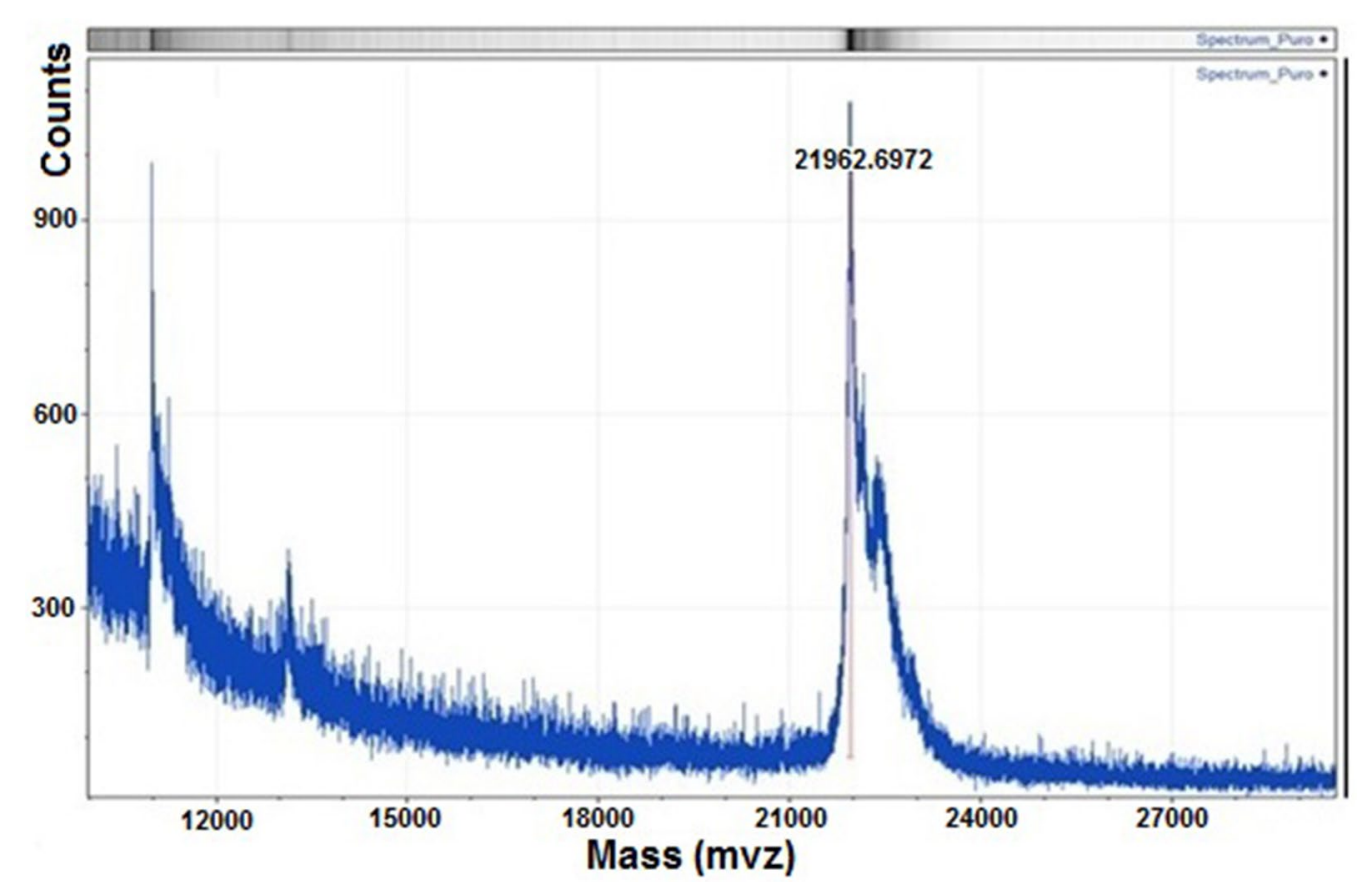

Fig.7 Example of the MALDI-TOF-MS analysis of purified $\Delta_{1-11}-$ G129R-hPRL

the antagonist S179D-hPRL was insufficient for further studies (Ueda et al. 2009).

It is widely known that periplasmic expression has in general much lower yields (up to $>100$-fold lower) than cytoplasmic expression. We can for example compare the $\mathrm{hPRL}$ cytoplasmic expression of $\left.132.7 \mu \mathrm{g} / \mathrm{mL} / \mathrm{A}_{600}\right)$ (Affonso et al. 2018) with the periplasmic expression of $0.93 \mu \mathrm{g} / \mathrm{mL} / \mathrm{A}_{600)}$ reported by Soares et al. (2008) for the same hormone. Considering other authors, we should mention the production obtained in the cytoplasm by Goffin et al. (1994) for several hPRL analogues, that was of the order of $150 \mu \mathrm{g} / \mathrm{mL}$. The quite low specific expression of our antagonist, mentioned above and obtained in erlenmayer flasks, can be greatly improved under controlled bioreactor conditions as reported by our research group in the case of hPRL production (Soares et al. 2008).

\section{Purification of $\Delta_{1-11}$-G129R-hPRL from periplasmic fluid}

The first purification step of the present prolactin variant obtained from periplasmic fluid required $80 \mathrm{mM}$ Imidazole. A lower molarity of $60 \mathrm{mM}$ imidazole was used instead for hPRL elution in previous work (Ueda et al. 2001). The recovery in the IMAC step was lower than that previously obtained for hPRL: $84 \%$ (Ueda et al. 2001). The recovery from SEC was similar to that reported for G120R-hGH: $69 \%$ (Menezes et al. 2017).

\section{In vitro biological activity determination}

Besides having shown no agonistic effect on mouse lymphoblastic cells proliferation, $\Delta_{1-11}$-G129R-hPRL antagonism versus hPRL (23\%) was well above the one that we determined in previous work analyzing G120RhGH (7\%) (Menezes et al. 2017). Bernichtein et al. (2003a, b, c) reported for $\Delta_{1-9}$-G129R-hPRL or $\Delta_{1-14}$-G129RhPRL a $50 \%$ antagonistic activity with a 100 -fold antagonist molar excess or almost $100 \%$ with a 1000 -fold molar excess, while Oclon et al. (2018) reported a 99\% antagonist activity with a 100 -fold molar excess of $\Delta_{1-9^{-}}$G129RhPRL. We suggest that the assay on the antagonistic effect should be standardized to a 1000 -fold molar excess of antagonist as reported by Bernichtein et al. (2003a, b, c), to facilitate inter-laboratory comparisons.

Human PRL receptor is activated by prolactin, growth hormone and placental lactogens (Bernichtein et al 2003a, b, c). It is of note that, in the case of hPRL, even if the 13 first residues are removed, the hormone bioactivity is not affected in either the $\mathrm{Ba} / \mathrm{F} 3-\mathrm{LP}$ or $\mathrm{Nb} 2$ rat cell assays (Jomain et al. 2007).

Since the full spectrum of functions of prolactin in health and disease, not only in humans, but in all vertebrates, is not completely understood (Bernard et al. 2019), the $\Delta_{1-11}$-G129R-hPRL may be important for further in vivo and in vitro studies. In view of clinical applications in the field of theranostic drug compounds, the binding of this molecule to iodine 131, gallium 67 or lutetium 177 

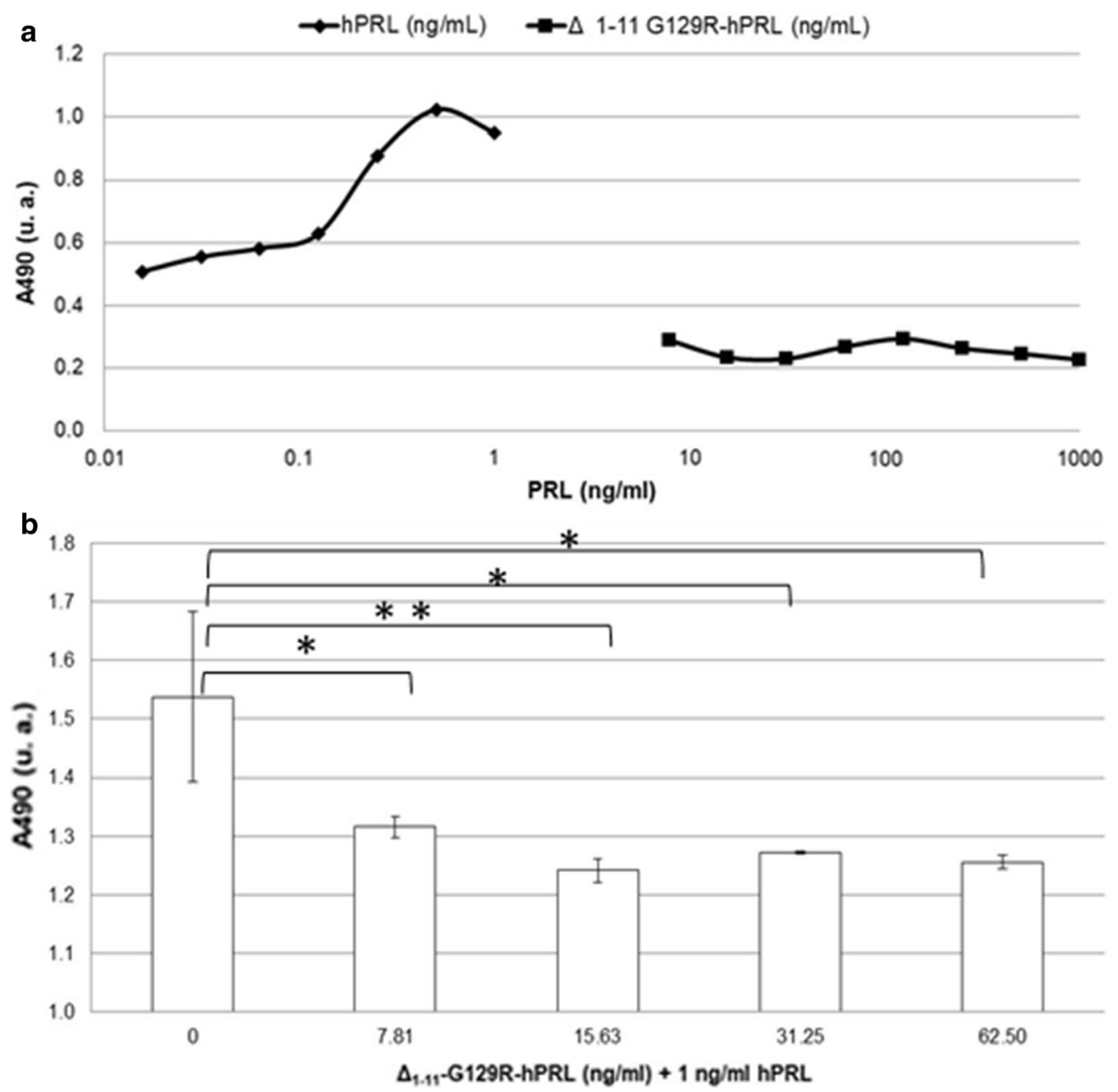

Fig. 8 Agonistic (a) and antagonistic (b) effects of $\triangle_{1-11}-G 129 R-h P R L$ in the proliferation assay based on Ba/F3-LLP cells. When the antagonist was added, the difference relative to the control was always significant: ${ }^{*} \mathrm{P}<0.02$; ${ }^{*} \mathrm{P}<0.05$

Table 2 Antagonistic effect of different concentrations of $\triangle_{1-11^{-}}$ G129R-hPRL, in the presence of $1 \mathrm{ng} / \mathrm{mL}$ of $\mathrm{hPRL}$, on Ba/F3-LLP cells proliferation

\begin{tabular}{|c|c|c|c|c|c|}
\hline $\begin{array}{l}\Delta_{1-11}-\mathrm{G} 129 \mathrm{R}- \\
\mathrm{hPRL}(\mathrm{ng} / \\
\mathrm{mL})\end{array}$ & $\begin{array}{l}\text { Exp. } \\
1\left(A_{490}\right.\end{array}$ & $\begin{array}{l}\text { Exp. } 2 \\
\left(A_{490}\right)\end{array}$ & $\begin{array}{l}\text { Exp. } \\
3\left(A_{490}\right.\end{array}$ & $\begin{array}{l}\text { Mean } \pm \text { SD } \\
\left(A_{490}\right)\end{array}$ & CV (\%) \\
\hline 0.00 & 1.71 & 1.46 & 1.45 & $1.54 \pm 0.14$ & 9.43 \\
\hline 7.81 & 1.30 & 1.31 & 1.34 & $1.32 \pm 0.02$ & 1.35 \\
\hline 15.63 & 1.26 & 1.24 & 1.22 & $1.24 \pm 0.02$ & 1.66 \\
\hline 31.25 & 1.27 & 1.27 & 1.27 & $1.27 \pm 0.01$ & 0.18 \\
\hline 62.50 & 1.26 & 1.26 & 1.24 & $1.26 \pm 0.01$ & 0.93 \\
\hline
\end{tabular}

SD: standard deviation; CV: coefficient of variation could be useful for diagnosis and therapy. $\Delta_{1-11}-\mathrm{G} 129 \mathrm{R}$ hPRL should also be tested for the inhibition of cancer cell proliferation overexpressing the prolactin receptor (Cheal et al. 2018) or for the control of blood glucose levels in individuals with insulin resistance (Furigo et al. 2019). Its possible therapeutic applications will take advantage of having obtained this antagonist without an initial methionine and directly in its soluble and correctly folded form.

\section{Acknowledgements}

The authors are grateful to the Centro de Facilidades de Apoio à Pesquisa of the University of São Paulo (CEFAP/USP, Mass Spectrometry and Proteome Research, Biomass Team) and to the CENTD of the Instituto Butantan (Centre of Excellence in New Target Discovery), for mass determination and the Centro de Estudos do Genoma Humano of the University of São Paulo (CEGH-IBUSP) for the plasmid sequence. 


\begin{abstract}
Authors' contributions
PB, CRJS and MFS designed the protocols of the study. JEO, LAA, SAP, RPF and FDS performed the experimental work and collected the data presented in the study. PB was involved in the statistical analyses. PB, RA and CRJS supervised the work. PB drafted the manuscript, although all authors contributed to conceptualizing and implementing the experiments. All authors read and approved the final manuscript.
\end{abstract}

\section{Funding}

This work was supported by The State of São Paulo Research Foundation (FAPESP), São Paulo, Brazil (Project Numbers 2012/24345-4; 2015/26058-0; 2017/50332-0); The National Council for Scientific and Technological Development (CNPq), Brasilia, Brazil (Project Number 3152/2018-3) and DPDE/IPEN, São Paulo, Brazil (Project Number 4/2017).

\section{Availability of data and materials}

Not applicable.

\section{Declarations}

Ethics approval and consent to participate

Not applicable.

\section{Consent for publication}

Not applicable.

\section{Competing interests}

The authors declare no competing interests.

Received: 11 March 2021 Accepted: 16 March 2021

Published online: 27 April 2021

\section{References}

Affonso R, Soares CR, Ribela MT, Bartolini P (2018) High production and optimization of the method for obtaining pure recombinant human prolactin. Protein Expres Purif 152:131-136

Ben-Jonathan N, Mershon JL, Allen DL, Steinmetz RW (1996) Extrapituitary prolactin: distribution, regulation, functions, and clinical aspects. Endocr Rev 17(6):639-669. https://doi.org/10.1210/edrv-17-6-639

Bernard V, Young J, Binart N (2019) Prolactin - a pleiotropic factor in health and disease. Nat Rev Endocrinol 15(6):356-365. https://doi.org/10. 1038/s41574-019-0194-6

Bernichtein S, Jeay S, Vaudry R, Kelly PA, Goffin V (2003a) New homologous bioassays for human lactogens show that agonism or antagonism of various analogs is a function of assay sensitivity. Endocrine 20:177-190. https://doi.org/10.1385/ENDO:20:1-2:177

Bernichtein S, Jomain JB, Kelly PA, Goffin V (2003b) The N-terminus of human prolactin modulates its biological properties. Mol Cell Endocrinol 208(1-2):11-21. https://doi.org/10.1016/s0303-7207(03)00264-8

Bernichtein S, Kayser C, Dillner K, Moulin S, Kopchick JJ, Martial JA, Norstedt G, Isaksson O, Kelly PA, Goffin V (2003c) Development of pure prolactin receptor antagonists. J Biol Chem 278(38):35988-35999. https://doi. org/10.1074/jbc.M305687200

Capone MV, Suzuki MF, Oliveira JE, Damiani R, Soares CR, Bartolini P (2015) $\mathrm{N}$-glycoprofiling analysis in a simple glycoprotein model: a comparison between recombinant and pituitary glycosylated human prolactin. J Biotechnol 202:78-87. https://doi.org/10.1016/j.jbiotec.2014.11.034

Cheal SM, Ruan S, Veach DR, Longo VA, Punzalan BJ, Wu J, Fung EK, Kelly MP, Kirshner JR, Giurleo JT, Ehrlich G, Han AQ, Thurston G, Olson WC, Zanzonico PB, Larson SM, Carrasquillo JA (2018) ImmunoPET imaging of endogenous and transfected prolactin receptor tumor xenografts. Mol Pharm 15(6):2133-2141. https://doi.org/10.1021/acs.molpharmac eut.7b01133

Chen NY, Holle L, Li W, Peirce SK, Beck MT, Chen WY (2002) In vivo studies of the anti-tumor effects of a human prolactin antagonist, hPRL-G129R. Int J Oncol 20(4):813-818. https://doi.org/10.3892/ijo.20.4.813

Chen TJ, Kuo CB, Tsai KF, Liu JW, Chen DY, Walker AM (1998) Development of recombinant human prolactin receptor antagonists by molecular mimicry of the phosphorylated hormone. Endocrinology 139(2):609616. https://doi.org/10.1210/endo.139.2.5758

Chen WY, Ramamoorthy P, Chen N, Sticca R, Wagner TE (1999) A human prolactin antagonist, hPRL-G129R, inhibits breast cancer cell proliferation through induction of apoptosis. Clin Cancer Res 5(11):3583-93. Erratum in: Clin Cancer Res 2000 6(5):2120.

Dalmora S, Oliveira JE, Affonso R, Gimbo E, Ribela MTP, Bartolini P (1997) Analysis of recombinant human growth hormone directly in osmotic shock fluids. J Chromatogr A 782:199-210. https://doi.org/10.1016/ s0021-9673(97)00493-7

Dias PVS, Arthuso FS, Oliveira JE, Suzuki MF, Sousa JM, Ribela MTCP, Bartolini $P$, Soares CRJ (2018) Determination of recombinant Interferon-a2 in $E$. coli periplasmic extracts by reversed-phase high-performance liquid chromatography. J Chromatogr B Analyt Technol Biomed Life Sci. 1072:193-198. https://doi.org/10.1016/j.jchromb.2017.11.023

Edman P, Begg G (1967) A protein sequenator. Eur J Biochem 1:80-91. https://doi.org/10.1007/978-3-662-25813-2_14

Ferraris J, Bernichtein S, Pisera D, Goffin V (2013) Use of prolactin receptor antagonist to better understand prolactin regulation of pituitary homeostasis. Neuroendocrinology 98:171-179. https://doi.org/10. $1159 / 000354701$

Furigo IC, Suzuki MF, Oliveira JE, Ramos-Lobo AM, Teixeira PDS, Pedroso JA, de Alencar A, Zampieri TT, Buonfiglio DC, Quaresma PGF, Prada PO, Bartolini P, Soares CRJ, Donato J Jr (2019) Suppression of prolactin secretion partially explains the antidiabetic effect of bromocriptine in ob/ob mice. Endocrinology 160(1):193-204. https://doi.org/10.1210/ en.2018-00629

Glezer A, Soares CRJ, Vieira JG, Giannella-Neto D, Ribela MTCP, Goffin V, Bronstein MD (2006) Human Macroprolactin displays low biological activity via its homologous receptor in a new sensitive bioassay. J Clin Endocrinol Metab 91(3):1048-1055. https://doi.org/10.1210/jc.2005-1831

Goffin V, Struman I, Mainfroid V, Kinet S, Martial JA (1994) Evidence for a second receptor binding site on human prolactin. J Biol Chem 269(51):32598-32606

Goffin V (2017) Prolactin receptor targeting in breast and prostate cancers: new insights into an old challenge. Pharmacol Ther 179:111-126. https:// doi.org/10.1016/j.pharmthera.2017.05.009

Jomain JB, Tallet E, Broutin I, Hoos S, van Agthoven J, Ducruix A, Kelly PA, Kragelund BB, England P, Goffin V (2007) Structural and thermodynamic bases for the design of pure prolactin receptor antagonists: X-ray structure of Del1-9-G129R-hPRL. J Biol Chem 282(45):33118-33131. https:// doi.org/10.1074/jbc.M704364200

Laemmli UK (1970) Cleavage of structural proteins during the assembly of the head of bacteriophage T4. Nature 227:680-685. https://doi.org/10.1038/ $227680 \mathrm{a0}$

Menezes A, Suzuki MF, Oliveira JE, Ribela MTP, Furigo IC, Donato J Jr, Bartolini P, Soares CRJ (2017) Expression, purification and characterization of the authentic form of human growth hormone receptor antagonist G120RhGH obtained in Escherichia coli periplasmic space. Protein Expr Purif 131:91-100. https://doi.org/10.1016/j.pep.2016.12.001

Morganti L, Soares CRJ, Affonso R, Gout PW, Bartolini P (1998) Synthesis and characterization of recombinant, authentic human prolactin secreted into the periplasmic space of Escherichia coli. Biotech Appl Biochem 27(1):63-70. https://doi.org/10.1111/j.1470-8744.1998.tb01375.x

Oclon E, Solomon G, Hayouka Z, Salame TM, Goffin V, Gertler A (2018) Novel reagents for human prolactin research: large-scale preparation and characterization of prolactin receptor extracellular domain, non-pegylated and pegylated prolactin and prolactin receptor antagonist. Protein Eng Des Sel 31(1):7-16. https://doi.org/10.1093/protein/gzx062

O'Sullivan CC, Bates SE (2016) Targeting prolactin receptor (PRLR) signaling in PRLR-positive breast and prostate cancer. Oncologist 21:523-526. https:// doi.org/10.1634/theoncologist.2016-0108

Paraiba DB, Soares CR, Bartolini P, Arthuso FS, Borba EF, Bonfa E, Bronstein MD (2010) Lymphocytic prolactin does not contribute to systemic lupus erythematosus hyperprolactinemia. Clin Exp Rheumat 28(6):866-872

Silva FD, Oliveira JE, Freire RP, Suzuki MF, Soares CR, Bartolini P (2019) Expression of glycosylated human prolactin in HEK293 cells and related N-glycan composition analysis. AMB Express 9(1):135. https://doi.org/10. 1186/s13568-019-0856-8 
Sinha YN (1992) Prolactin variants. Trends Endocrinol Metab 3(3):100-106. https://doi.org/10.1016/1043-2760(92)90021-r

Soares CR, Camargo IM, Morganti L, Gimbo E, Oliveira JE, Legoux R, Ferrara P, Bartolini P (2002) Reversed phase high-performance liquid chromatography method for the determination of prolactin in bacterial extracts and in its purified form. J Chromatogr A 955:229-236. https://doi.org/10.1016/ s0021-9673(02)00229-7

Soares CR, Glezer A, Okazaki K, Ueda EK, Heller SR, Walker AM, Goffin V, Bartolini P (2006) Physico-chemical and biological characterizations of two human prolactin analogs exhibiting controversial bioactivity, synthesized in Chinese hamster ovary (CHO) cells. Protein Expr Purif 48(2):182-194. https:// doi.org/10.1016/j.pep.2006.04.013

Soares CR, Gomide FI, Ueda EK, Bartolini P (2003) Periplasmic expression of human growth hormone via plasmid vectors containing the lambdaPL promoter: use of HPLC for product quantification. Protein Eng 16(12):1131-1138. https://doi.org/10.1093/protein/gzg114

Soares CR, Ueda EK, Oliveira TL, Gomide FI, Heller SR, Bartolini P (2008) Distinct human prolactin (hPRL) and growth hormone $(\mathrm{hGH})$ behavior under bacteriophage lambda PL promoter control: temperature plays a major role in protein yields. J Biotech 133(1):27-35. https://doi.org/10.1016/j. jbiotec.2007.08.038

Sockolosky JT, Szoka FC (2013) Periplasmic production via the pET expression system of soluble, bioactive human growth hormone. Protein Expr Purif 87:129-135. https://doi.org/10.1016/j.pep.2012.11.002

Suzuki MF, Arthuso FS, Oliveira JE, Oliveira NAJ, Goulart HR, Capone MVN, Ribela MTCP, Bartolini P, Soares CRJ (2012) Expression, purification, and characterization of authentic mouse prolactin obtained in Escherichia coli periplasmic space. Biotech App Biochem 59(3):178-185. https://doi.org/ 10.1002/bab.1008

Swiech K, Picanco-Castro V, Covas DT (2012) Human cells: new platform for recombinant therapeutic protein production. Protein Expr Purif 84:147-153. https://doi.org/10.1016/j.pep.2012.04.023

Taherian E, Mohammadi E, Jahanian-Najafabadi A, Moazen F, Akbari V (2019) Cloning, optimization of periplasmic expression and purification of recombinant granulocyte macrophage-stimulating factor in Escherichia coli BL21 (DE3). Adv Biomed Res 8:71. https://doi.org/10.4103/abr.abr_ 166_19
Tallet E, Rouet V, Jomain JB, Kelly PA, Bernichtein S, Goffin V (2008) Rational design of competitive prolactin/growth hormone receptor antagonists. J Mammary Gland Biol Neoplasia 13(1):105-117. https://doi.org/10.1007/ s10911-008-9066-8

Ueda E, Ozerdem U, Chen YH, Yao M, Huang KT, Sun H, Martins-Green M, Bartolini P, Walker AM (2006) A molecular mimic demonstrates that phosphorylated human prolactin is a potent anti-angiogenic hormone. Endocr Relat Cancer 13(1):95-111. https://doi.org/10.1677/erc.1.01076

Ueda EK, Gout PW, Morganti L (2001) Ni(II)-based immobilized metal ion affinity chromatography of recombinant human prolactin from periplasmic Escherichia coli extracts. J Chromatogr A 922:165-175. https://doi.org/10. 1016/s0021-9673(01)00875-5

Ueda EK, Soares CR, Bartolini P, DeGuzman A, Lorenson MY, Walker AM (2009) A molecular mimic of phosphorylated prolactin (S179D PRL) secreted by eukaryotic cells has a conformation with an increased positive surface charge compared to that of unmodified prolactin. Biochemistry 48(29):6887-6897. https://doi.org/10.1021/bi9004864

Xu X, Kreye E, Kuo CB, Walker AM (2001) A molecular mimic of phosphorylated prolactin markedly reduced tumor incidence and size when DU145 human prostate cancer cells were grown in nude mice. Cancer Res 61(16):6098-6104

Yu S, Alkharusi A, Norstedt G, Gräslund T (2019) An in vivo half-life extended prolactin receptor antagonist can prevent STAT5 phosphorylation. PLoS ONE 14(5):e0215831. https://doi.org/10.1371/journal.pone.0215831

\section{Publisher's Note}

Springer Nature remains neutral with regard to jurisdictional claims in published maps and institutional affiliations.

\section{Submit your manuscript to a SpringerOpen ${ }^{\circ}$ journal and benefit from:}

- Convenient online submission

- Rigorous peer review

- Open access: articles freely available online

- High visibility within the field

- Retaining the copyright to your article

Submit your next manuscript at $\gg$ springeropen.com 